\title{
Varying degradation of subfossil Daphnia longispina during the past 250 years and the discovery of fossil helmet-type head shields: preliminary results
}

\author{
Jaakko Johannes Leppänen, ${ }^{*}$ Jan Weckström \\ Department of Environmental Sciences, University of Helsinki, P.O. Box 65, FIN-00014, Finland \\ *Corresponding author jaakko.leppanen@helsinki.fi
}

\begin{abstract}
Zooplankton are regarded as a good indicator of environmental change, but comprehensive monitoring programs including zooplankton are uncommon and only rarely extend over longer periods of time. A part of the zooplankton community can be reconstructed using palaeolimnological methods, yet challenges remain. For example, cladoceran subfossil remains preserve selectively in sediments. In particular, the remains of Daphnia spp. are known to usually exhibit poor level of preservation; the reasons for this are still unclear. In the rural Lake Kivijärvi, located in central Finland, Daphnia subfossil remains preserve extraordinary well and multiple fossil components are found. However, the preservation level is not uniform and exhibits directional change throughout the sediment record. To investigate the changes in Daphnia preservation in lake sediments, we graded caudal spines from 20 fossil sediment samples into three taphonomic groups. A dataset of sediment geochemistry, diatom-inferred lake water $\mathrm{pH}$, predation indices, and the catchment land use history was used to assess the environmental history of our study lake. In Lake Kivijärvi, the most significant change in Daphnia preservation seems to correspond best with the historical fishing activities. Additional explanatory variables include forestry in the catchment area, and $\mathrm{pH}$, which, however, had contradicting effects on the preservation of Daphnia remains in this study. Finally, a fossil Daphnia longispina helmet type head shield derived from the lake sediment is presented for the first time.
\end{abstract}

Key words: Daphnia; preservation; subfossil; palaeolimnology; cladocera.

Received: September 2016. Accepted: November 2016.

\section{INTRODUCTION}

Palaeolimnological tools can be applied to reveal information retained in aquatic sediments (Smol 1992, European Union 2000). Cladocerans (Branchiopoda: Phyllopoda), which have been demonstrated to be excellent indicators of environmental change (Eggermont and Martens, 2011), have been used in palaeolimnological studies to reconstruct past environmental conditions of lake ecosystems since the 1950s (Frey, 1986). Despite their obvious value, methodological limitations and sources of error still exist. Cladoceran remains, for example, preserve selectively in lake sediments, as some species and some components preserve better than others. In the case of Daphniids O.F. Müller, only postabdomal claws and resting spores (ephippia) are typically found in sediments (Schmidt et al., 1998; Korhola, 1999; SarmajaKorjonen, 2002), while the small size of their claws inflicts an elevated risk of losing claws during sieving. This may lead to an underestimation of Daphnia O. F. Müller abundance when it is based on the number of claws (Nykänen et al., 2009). The poor preservation of Daphnia is particularly problematic, because Daphnia is by far the most studied cladoceran taxon (Ebert, 2005). For example, Peters and de Bernardi (1987) and Lampert (2011) published comprehensive reviews of Daphnia ecology, and the number of scientific articles on Daphnia indexed in the Thomson Reuters Web of Science exceeds 10000 (Seda and Petrusek, 2011). Nevertheless, Daphnia remains do preserve well in some lakes, such as in Lake Kivijärvi (Finland), although the reasons behind this variation in preservation are not yet fully understood. The preservation issues in sedimentary cladocerans have been studied before (Deevey, 1964; Kerfoot, 1981), but we are unaware of previous research attempting to assess the variations in Daphnia degradation in a sediment core.

In this study we combined data on Daphnia preservation to sedimentary geochemistry, diatom-inferred lake water $\mathrm{pH}$, predation indices and known land use and fishing history of Lake Kivijärvi in order to shed new light on the preservation issues of Daphnia remains.

\section{METHODS}

\section{Study area}

Lake Kivijärvi is a small $\left(1.8 \mathrm{~km}^{2}\right)$, relatively deep (max depth $12 \mathrm{~m}$ ), brown-coloured lake, which is surrounded by mires and coniferous forests. It is located at $165 \mathrm{~m}$ asl in central northern Finland (N 63 ${ }^{\circ} 55.998^{\prime} \mathrm{E}$ $\left.27^{\circ} 54.281^{\prime}\right)$. During the summer stratification in August 2006 , which corresponds to the age of our topmost sedi-

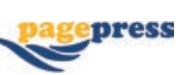


ment sample, the lake surface water $(1 \mathrm{~m})$ was slightly acidic ( $\mathrm{pH}$ 6.2), with an alkalinity of $59 \mu \mathrm{mol} \mathrm{L}^{-1}$ and conductivity of $19 \mu \mathrm{S} \mathrm{cm}^{-1}$. The total phosphorus and total nitrogen concentrations measured during this period were $33 \mu \mathrm{g} \mathrm{L}^{-1}$ and $540 \mu \mathrm{g} \mathrm{L}^{-1}$, respectively, and the chlorophyll- $a$ concentration $22 \mu \mathrm{g} \mathrm{L}^{-1}$. The lake is fed by River Lumijoki and the brook Myllypuro. Human activities, such as land use and fishing have affected the lake since the beginning of the $20^{\text {th }}$ century. The catchment area (53 $\mathrm{km}^{2}$ ) has been heavily ditched during forestry practices, which were most intense during the 1960s and 1970s. In addition, one peat extraction area (33 ha) located in the western part of the Kivijärvi catchment operated between 1986 and 2012 (N. Huotari, personal communication). Today the proportion of the ditched area in the lake catchment is over $40 \%$. More recent disturbances (since 2008) include sulphate and metal pollution from the Talvivaara $\mathrm{Ni}-\mathrm{Cu}-\mathrm{Zn}$-Co mine, which is connected to Lake Kivijärvi via Lumijoki River and is located approx. $6 \mathrm{~km} \mathrm{NE}$ from Lake Kivijärvi (Kauppi et al., 2013). The average (19712000) yearly air temperature and precipitation are $+2^{\circ} \mathrm{C}$ and $\sim 600 \mathrm{~mm}$, respectively (Kersalo and Pirinen, 2009). Annual precipitation has increased by an estimated 0.92 $\mathrm{mm} \pm 0.50 \mathrm{~mm}$ year ${ }^{-1}$ (Irannezhad et al., 2014) during the last century and mean air temperature has increased by $2{ }^{\circ} \mathrm{C}$ during the past 166 years (Mikkonen et al., 2014).

Bathymetric data was obtained from the Finnish Environment Institute electronic GIS library (http://wwwd3.ymparisto.fi/d3/wmsrajapinta.htm), the catchment area was determined using the online tool VALUE provided by the Finnish Environmental Institute (http://paikkatieto.ymparisto.fi/value/) and was analysed using the geographical information system program ESRI ArcMap 10.2.1. Water chemistry data was obtained from the OIVA database (Finnish Environment Institute, https://wwwp2.ymparisto. fi/scripts/oiva.asp). Data regarding forestry activity between 1966 and 1994 was obtained from historical map archives of the National Land Survey of Finland (http://vanhatpainetutkartat.maanmittauslaitos.fi/).

\section{Coring}

Two short sediment cores were retrieved from the northern section of Lake Kivijärvi (N 63 55.998'E $27^{\circ}$ 54.281' WGS84, at the depth of $8 \mathrm{~m}$ ) using a HTH-Kajak sediment corer with a diameter of $9 \mathrm{~cm}$ (Renberg and Hansson, 2008).

Core A (26 cm length) was used for sediment dating, and for analyses of sub-fossil cladocerans and diatoms, core B $(24 \mathrm{~cm})$ was used for elemental analysis. The cores were subsampled at $0.25 \mathrm{~cm}$ intervals for the first $5 \mathrm{~cm}$ and at $1 \mathrm{~cm}$ intervals between 5 and $26 \mathrm{~cm}$. The initial reason for different subsampling for the first $5 \mathrm{~cm}$ was to provide possibility for high resolution assessment of known mine pollution, which is affecting lake water quality since
2008. Mining effluent has resulted in elevated lake metal $(\mathrm{Fe}, \mathrm{Mn}, \mathrm{Ni}, \mathrm{Zn})$ and salt $(\mathrm{NaSO})$ concentrations, and has turned the lake meromictic (Kauppi et al., 2013). Subsampling was conducted in the field and the samples were stored in plastic zip lock bags and stored in a dark cold room at $4^{\circ} \mathrm{C}$. As the two cores were retrieved from the flat and large center of the lake and less than $1.5 \mathrm{~m}$ apart from each other, the temporal resolution of these two cores can be assumed as comparable. Nevertheless, the cores were correlated based on their visual features. Both cores exhibited analogous and clear changes in sediment composition in the top first $\mathrm{cm}$, where the sulfur rich layer originating from the mine pollution disappeared strictly at $0.75-1 \mathrm{~cm}$ level. Moreover, both cores showed a clear transition layer between 4 and $6 \mathrm{~cm}$, where the sediment color changed to darker brown. Below this, both cores showed unchanged sediment color and texture. The top $0-1 \mathrm{~cm}$ core samples were omitted from the study, as they were deposited after the onset of mine pollution and therefore strongly affected by metals and sulphur, which caused the almost complete disappearance of Daphnia remains.

\section{Dating and sediment chemistry}

Freeze dried sediment samples from core A were radiometrically dated at the Liverpool University Environmental Laboratory, using Ortec HPGe GWL well-type coaxial low background intrinsic germanium detectors (Appleby et al., 1986). The samples were analysed for ${ }^{210} \mathrm{~Pb},{ }^{226} \mathrm{Ra},{ }^{137} \mathrm{Cs}$ and ${ }^{241} \mathrm{Am}$ by direct gamma assay. Elemental concentrations of erosion indicators magnesium $(\mathrm{Mg})$, potassium $(\mathrm{K})$ and sodium $(\mathrm{Na})$ were analysed in the acid soluble $\left(\mathrm{NHO}_{3}\right)$ sediment fractions in the Metropolilab Environmental laboratory at Helsinki, which is an accredited testing laboratory (FINAS T058).

\section{Daphnia analysis}

Each sediment subsample $\left(\sim 1 \mathrm{~cm}^{3}\right.$ of wet material) was treated using $10 \% \mathrm{KOH}$ solution, heated $\left(80^{\circ} \mathrm{C}\right)$ on a hotplate for $30 \mathrm{~min}$, and sieved through $48 \mu \mathrm{m}$ mesh size with tap water. Samples were mounted with safranine stained glycerol. For more information regarding the protocol, see Szeroczyñska and Sarmaja-Korjonen (2007). Daphnia remains were identified and counted using both 200 and $400 \mathrm{x}$ magnifications. During the preliminary microscopic screening, a broad variation in the preservation of postabdominal claws was observed, e.g. notable variations in type and magnitude of damage in claws, denticles and setae. In addition, also the size of the claws showed large variability, which, in turn, has a direct impact on their resistance to damage. Classification of claws was thus found to be extremely difficult, whereas the differences in degree of preservation were clearer for caudal spines. Caudal spines were therefore identified as the most 
suitable component to study the variance in preservation of subfossil Daphnia. To evaluate these preservation differences, 100 spines from each one of the 20 sediment subsamples were identified and assessed for a taphonomic grade. Taphonomic grading is used in palaeoecology to assess the deposition speed and reworking of fossil assemblages (Brandt, 1989). The studies regarding microbial decomposition of Daphnia remains are rare, but it has been reported that Daphnia remains are rapidly and heavily colonized by chitin degrading microbes (Tang et al., 2009) and fungi (Czezuga et al., 2002). The colonization by degrading organisms would imply a rather even and comprehensive degradation within a certain sediment layer than mechanical impacts. In the present work each spine was graded in relation to its stiffness, folding and breakage (Tab. 1; Fig. 1). We assumed that folded or broken spines have been damaged due to mechanical impact, and spines that have completely lost their form (slack spines) have been affected by microbial or chemical degradation.

\section{Predation assessment}

To assess changes in predation on cladocerans in Lake Kivijärvi, we conducted morphological measurements of Eubosmina longispina Leydig exoskeletal remains (36-46 measurements of carapace and mucro length per sample), and counted the Chaoborus spp. Lichtenstein, mandibles detected in the sediment subsamples to calculate the ratio (number of Chaoborus spp. mandibles: 100 Daphnia spines). The value as an ecological indicator of morphological changes within the genus Bosmina has been recently reviewed by Korosi et al. (2013), but the applicability of subgenera Eubosmina morphology is not so straight forward due to contrasting results in literature (Sprules et al., 1984; Johnsen and Raddum, 1987). In contrast, the abundance of Chaoborus larvae has been demonstrated to reflect the abundance of fish and to affect the cladoceran community structure (Sweetman and Smol, 2006).

\section{Numerical analysis}

The non-parametric Mann-Kendall trend test (Gilbert, 1987) was used to detect significant monotonic trends in the taphonomic grade data of sedimentary Daphnia remains. Constrained optimal sum of squares partitioning with untransformed species percentage data (Birks and Gordon, 1985) was used to detect significant zones in taphonomic stratigraphy. The number of statistically significant zones was calculated using the broken-stick model described in Bennett (1996). Optimal partitioning was conducted using the program ZONE 1.2 (Lotter and Juggins, 1991). The Mann-Kendall test was conducted with PAST statistics 3.10 software (Hammer et al., 2001).

Tab. 1. Taphonomic grades for Daphnia caudal spines.

\begin{tabular}{ccc} 
Excellent preservation & Fair preservation & Poor preservation \\
$\begin{array}{c}\text { Stiff and straight spines with } \\
\text { no visible damage }\end{array}$ & $\begin{array}{c}\text { Stiff and straight spines with } \\
\text { breakage and/or folding }\end{array}$ & $\begin{array}{c}\text { Slack spines. Initial shape is } \\
\text { no longer sustained }\end{array}$ \\
\hline
\end{tabular}

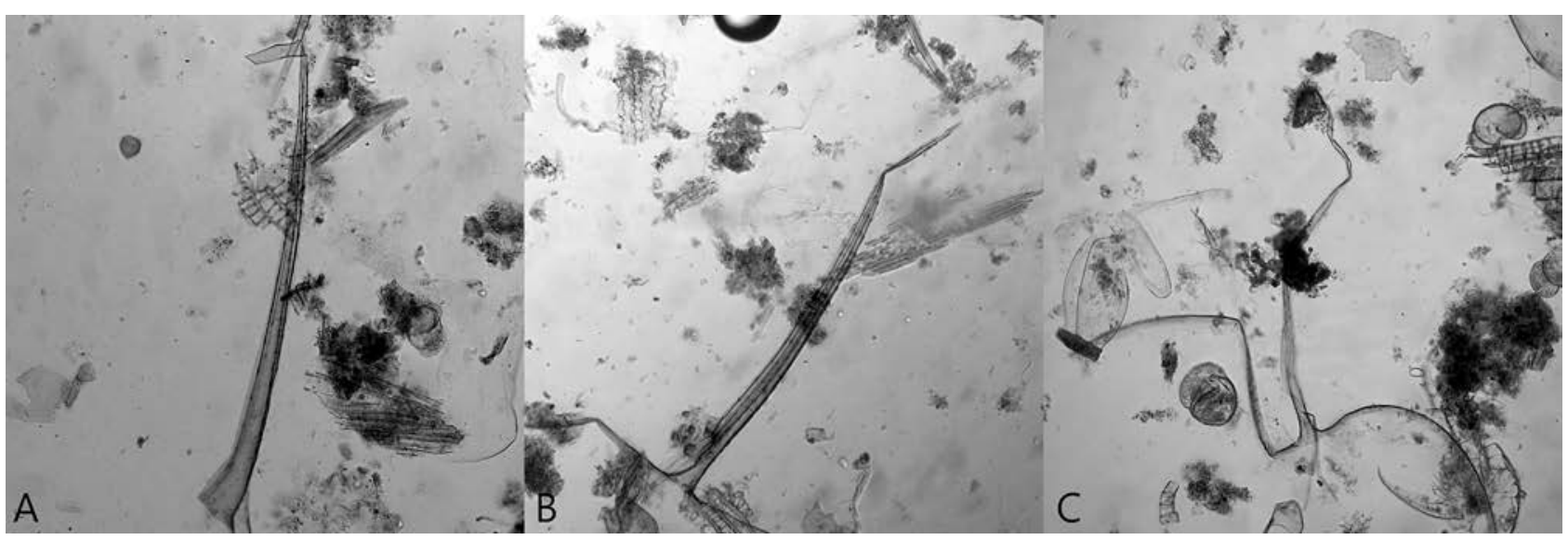

Fig. 1. A) An example of a well-preserved caudal spine graded as excellent. B) A relatively well preserved, but visibly damaged caudal spine graded as fair. C) A poorly preserved caudal spine graded as poor. 


\section{Diatom-inferred lake water pH (DI-pH)}

The pH history of Kivijärvi was quantitatively reconstructed using an independent modern diatom-water $\mathrm{pH}$ calibration data set consisting of 98 surface-sediment diatom assemblages from northern Finland and corresponding $\mathrm{pH}$ measurements (for more details see Seppä and Weckström, 1999; Väliranta et al., 2011). After testing different models (WA-inverse deshrinking, WA-classical deshrinking, Partial-Least-Squares) the 1-component weighted average partial least squares (WA-PLS) model provided the best performance with a coefficient of determination $\left(\mathrm{r}^{2}\right)$ of 0.68 and a root mean square error of prediction (RMSEP) of $0.31 \mathrm{pH}$ units. This diatom-based quantitative $\mathrm{pH}$ model was then applied to the fossil diatom data analyzed from Lake Kivijärvi. Methods and taxonomic literature used for diatom analyses are described in Weckström et al. (1997). The quantitative DI$\mathrm{pH}$ is inferred only for the depths of $1-16 \mathrm{~cm}$, as the original reason for constructing the DI-pH model was to study the recent impact of the Talvivaara mine on the Lake Kivijärvi water chemistry (unpublished data).

\section{RESULTS}

\section{Dating and sediment geochemistry}

According to the radiometric dating, the sediment depth of $2.5 \mathrm{~cm}$ records the fallout from Chernobyl reactor accident (AD 1986) and the depth of $4.5 \mathrm{~cm}$ records the fallout maximum from atmospheric nuclear weapons testing (AD 1963, Appleby et al., 1991). The dating provided a sedimentation rate of approximately $0.1 \mathrm{~cm}$ year $^{-1}$. Unsupported lead concentrations reach zero values at the depth of $10 \mathrm{~cm}$, which corresponds to the beginning of the $20^{\text {th }}$ century $(1910 \pm 8)$. Concentrations of $\mathrm{K}$ and $\mathrm{Mg}$ increased after 1925 and reached maximum values in the late 1990s (Fig. 2).

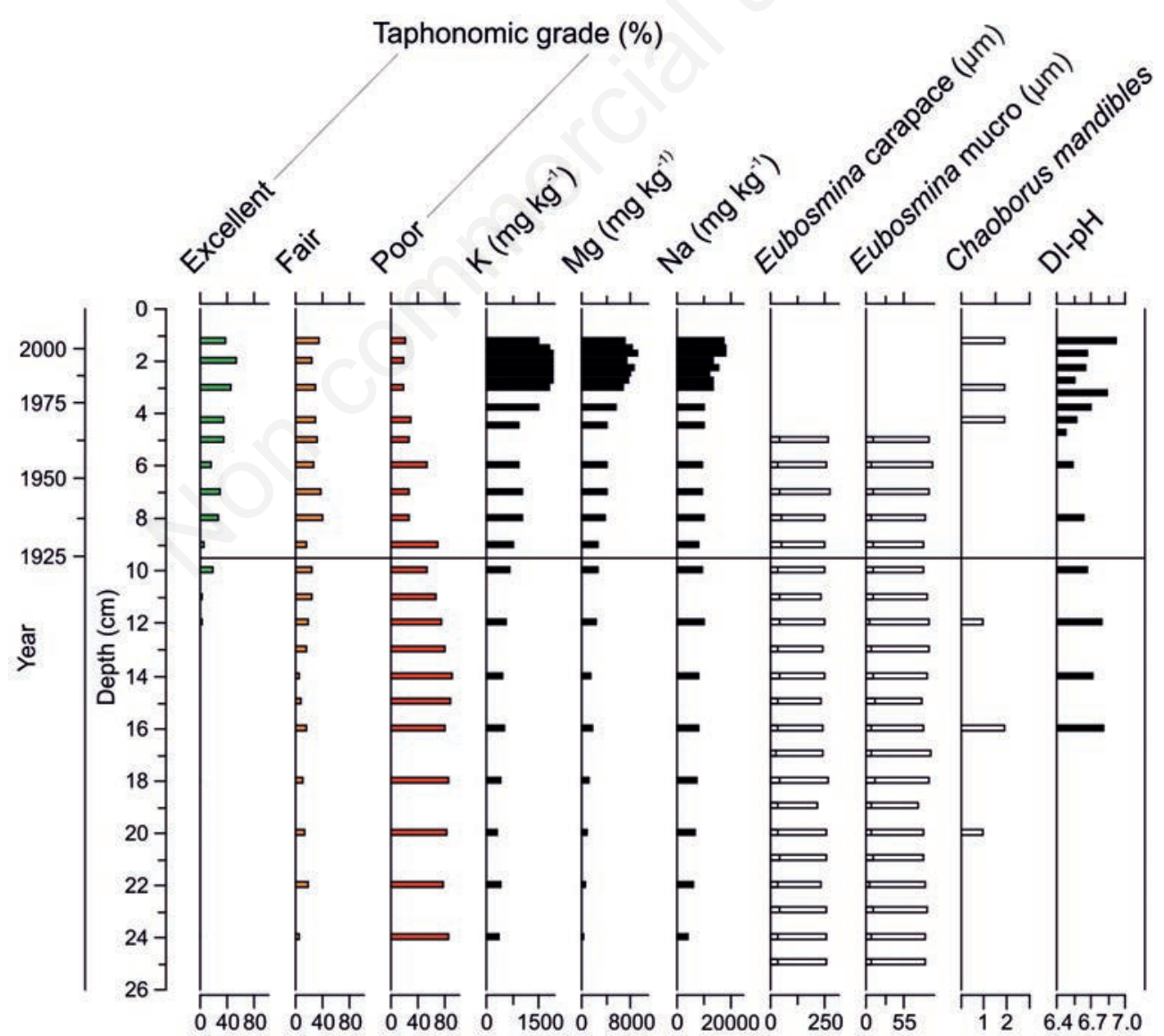

Fig. 2. Results of taphonomical stratigraphy, geological characteristics, predation indices and diatom-inferred lake pH. Eubosmina measurements are in $\mu \mathrm{m}$ (bar, average carapace length or mucro length; vertical line inside bar, standard deviation). Note that Eubosmina were not measured between depths $1-5 \mathrm{~cm}$. Chaoborus spp., number of Chaoborus spp. claws counted in each sample per 100 Daphnia spines. Horizontal line indicates the statistically significant shift in the preservation pattern. 


\section{Daphnia remains}

Many Daphnia remains were detected throughout the core, except for the top $0-1 \mathrm{~cm}$ section, where they were extremely rare, likely in relation to the impact of the mine pollution. In the other sediment layers, postabdominal claws, carapace, ephippia, caudal spines and head shields were present in large numbers. Only Daphnia longispina O.F. Müller -type postabdominal claws were detected. Head shields showed various degrees of preservation including many very well preserved helmet-type head shields (Fig. 3A), with one head shield still attached to the carapace (Fig. 3B). There was a significant increasing trend towards present in the proportion of caudal spines graded as excellent (Mann-Kendall: $\mathrm{Z}=3.88, \mathrm{~S}=103$, $\mathrm{P}<0.001$ ) and fair (Mann-Kendall: $\mathrm{Z}=3.53, \mathrm{~S}=94$, $\mathrm{P}<0.001$ ), and a significant decreasing trend in the proportion of caudal spines graded as poor (Mann-Kendall: $\mathrm{Z}=3.94, \mathrm{~S}=-105, \mathrm{P}<0.001)$. Zoning revealed two significant zones at depths 1-9 and 9-26 cm (Fig. 2).

\section{Predation assessment}

The length of the mucro and carapace of E. longispina exhibited no clear shifts within the core (Fig. 2). Measurements were terminated at the depth of $5 \mathrm{~cm}$ because of the appearance of Bosmina longirostris O. F. Müller in the sediment, as carapaces of $E$. longispina and B. longirostris are extremely difficult to be discriminated from each other.
Chaoborus mandibles were detected in very small numbers (0-2 mandibles per sample) throughout the core.

\section{DI-pH}

The DI-pH of the deepest core layers (which were likely deposited during the $18^{\text {th }}$ century), was comparable to DI-pH values around year 2000 (Fig. 2). However, DI$\mathrm{pH}$ started to decrease since the late $19^{\text {th }}$ century reaching the lowest values during the 1960s (Fig. 2). DI-pH remained at lower values between ca. 1920 and 1995, but later increased towards modern levels.

\section{DISCUSSION}

\section{Daphnia remains in Lake Kivijärvi}

Usually only Daphnia postabdomal claws and ephippia are found in lake sediments. Sometimes, as reported by Frey (1991), Mancini et al. (1999), and Sarmaja-Korjonen (2007), different components of Daphnia subfossils can stay relatively intact in the sediment for extended periods of time. Also Daphnia head shields have been detected in sediment samples (Frey, 1991; Mancini et al., 1999), but to our knowledge, helmet-type head shields of Daphnia longispina -group species have not been reported from lake sediment samples before. In the sediments of Lake Kivijärvi sediments, the Daphnia head shields appeared folded with fornices clearly visible, and

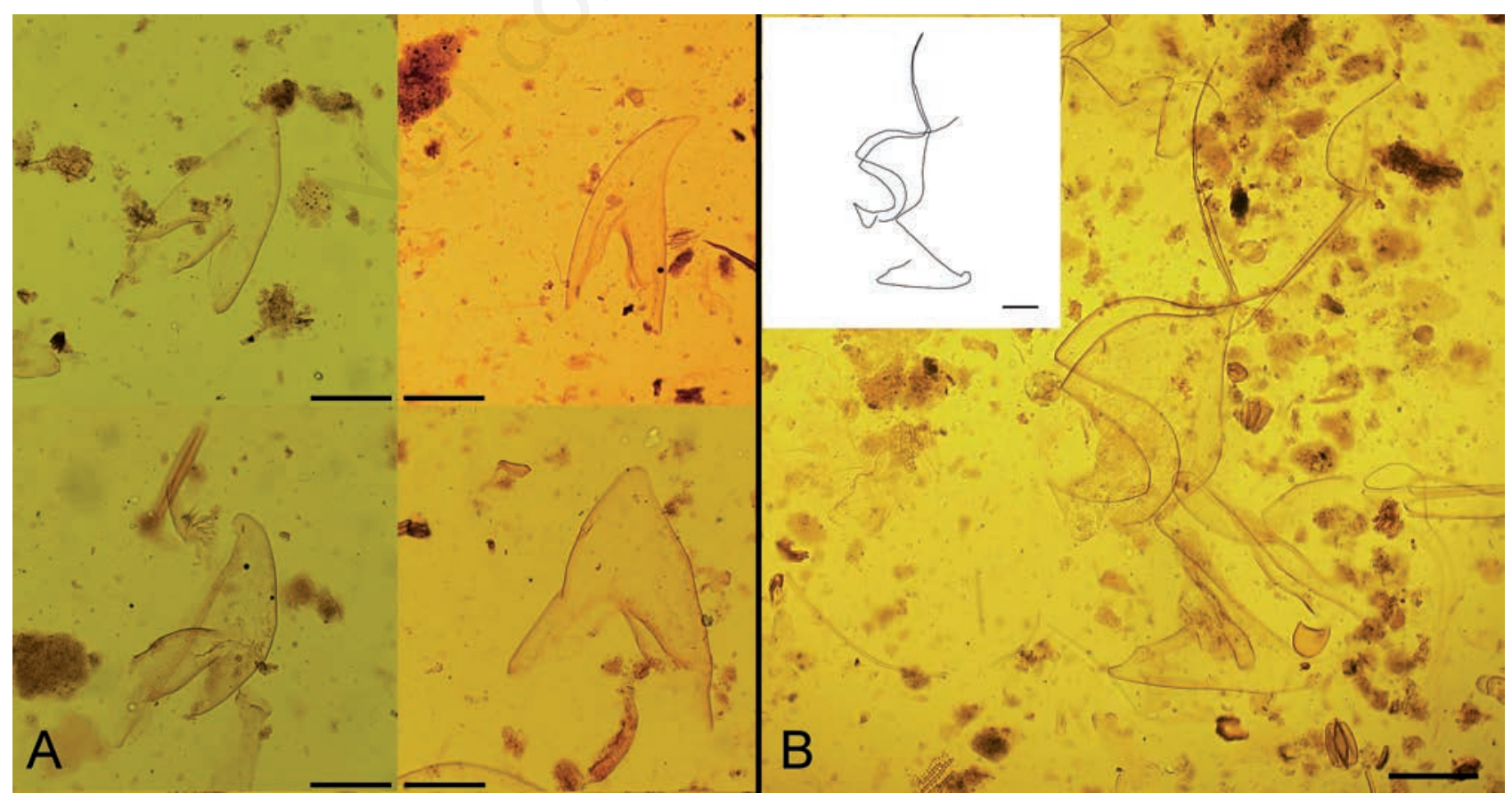

Fig. 3. A) Daphnia helmet type headshields. Scale bar: $100 \mu \mathrm{m}$. B) Daphnia headshield attached to carapace. 
a number of different structures were well preserved. However, the caudal spines showed the highest abundance. Even though postabdominal claws are usually used in research on subfossil Daphnia (Korosi et al., 2011), caudal spines were used in the present work, as they could be classified more easily due to their simpler form, while the classification of claws in relation to physical condition would have been very difficult due to the higher variability in their characteristics and damage magnitude. In addition, caudal spines exhibited one additional character of degradation, namely the total loss of form (slack spines). The spines graded as poorly preserved were slack, suggesting that their structure had been altered. According to Tang et al. (2009), cladoceran carcasses are rapidly and heavily colonized by chitin-degrading bacteria. Loss of form may therefore refer to microbial or chemical degradation, rather than to a mechanical impact. In addition, the loss of form can be considered as linked to autochthonous in-sediment processes, because, if the loss of form were a result of sample preparation, it should have affected similar proportions of spines in all samples. In contrast, spines graded as fair good preserved were almost intact apart from small breakages likely resulting from sample treatment (e.g., sieving) or from predator or scavenger attacks. Due to the uncertainty in pointing out whether the damage originates from laboratory treatment or from autochthonous processes, the indicator value of fair graded spines in this study is negligible.

\section{Changes in Daphnia preservation in Lake Kivijärvi}

According to the statistically significant core zonation, the greatest shift in Daphnia preservation occurred at the depth of $9 \mathrm{~cm}(\sim 1925)$ and was clearly reflected by changes in proportions of different grades. Though not statistically significant, also the depth of $12 \mathrm{~cm}(\sim$ pre 1900) clearly emerged as the level where early changes in Daphnia preservation onset. The $9 \mathrm{~cm}$ shift is most pronounced for the excellent and poor grades, whereas the change regarding spines graded as fairly preserved is not as distinct. Earlier studies suggest that Daphnia preservation is controlled by temperature (Szeroczyñska and Zawisza, 2005) or water chemistry (Sarmaja-Korjonen, 2007). However, changes in hypolimnetic temperatures of Lake Kivijärvi during the 1920s are not likely, because a most notable warming occurred in N-Finland only after the 1960s (Mikkonen et al., 2014). Moreover, hypolimnetic temperatures during stratification are not easily altered by relatively small scale increase in summer air temperatures (Arvola et al., 2010).

DI-pH showed a slight decrease since $\sim 1910$, which may have been related to natural acidification i.e. continuous leaching of buffering mineral elements like calcium $(\mathrm{Ca})$, potassium $(\mathrm{Na})$, magnesium $(\mathrm{Mg})$, and sodium $(\mathrm{K})$ (Pennington, 1984). In fact, the proportion of naturally acidified lakes is higher in central and norther Finland compared to $\mathrm{S}$ Finland, where anthropogenic acidification is more common (Meriläinen and Huttunen, 1990). The decrease in DI-pH since ca. 1910 corresponds relatively well to the change in Daphnia preservation, but effects of $\mathrm{pH}$ on preservation changes is not straight forward. In fact, preservation was not affected when $\mathrm{pH}$ increased since ca. 1995, thus contradicting the response during slight acidification at the beginning of the $20^{\text {th }}$ century. The lowest DI-pH values around 1960 could be due to the increased impact of acid rain on small freshwaters as sulphur emission in Finland increased substantially during the period of 1950-1970 (Kauppi et al., 1990). However, this period of lower $\mathrm{pH}$ seemed not to affect the preservation of Daphnia remains (Fig. 2).

The level of preservation of all subfossil material is usually related to accumulation rates, with good preservation (high taphonomic grade) reflecting fast accumulation and burial (Brandt, 1989). Since the core was only ${ }^{210} \mathrm{~Pb}$-dated, we lack dates previous to 1900 (i.e., below the depth of $10 \mathrm{~cm}$ ). As a consequence, the possibility of low sedimentation rates and subsequent poor preservation of Daphnia before ca. 1925 cannot be ruled out. Possible reasons behind major changes in the sedimentation rate during the pre-industrial era should be principally related to hydrological perturbations, such as water level manipulation and channel building. However, according to the map by Gylden (1848), shape and size of Kivijärvi did not change since the mid- $19^{\text {th }}$ century, which excludes any large-scale water works during the early $20^{\text {th }}$ century.

Cladoceran remains are directly affected by microbial degradation of chitin, which occurs both in the water and in the sediment (Swiontek Brzezinska et al., 2008). Bacteria are the most important responsible of chitin decomposition in aquatic environments (Aumen, 1980; Gooday, 1990), but there are indications that particularly Daphnia remains are attacked also by aquatic fungi (Czezuga et al., 2002). In addition, chemical changes of the sediments (diagenesis) may alter the conditions within the sediment and the degree of ongoing degradation of chitinous subfossil remains (Kidwell and Flessa, 1995). Forestry activities may affect lake water characteristics such as chemical oxygen demand (Ahtiainen, 1992; Rask et al., 1998), which in their turn may affect the fungal community (Wurzbacher et al., 2010) and slow down the bacterial decomposition of chitin (Köllner et al., 2012) at the sediment-water interface. However, documented forestry activities occurred well after the 1920 s, while the recent increasing concentrations of erosion indicators (Virkkanen and Tikkanen, 1998) in the studied sediment core started only during the last decades of the $19^{\text {th }}$ century. In addition to forestry actions, also changes in lake productivity could affect microbial community (Naeher et al., 2012). However, according to the available maps and per- 
sonal communication by S. Peronius, no farmland existed within the catchment during the early $20^{\text {th }}$ century. Moreover, the first residents occupying the lake's shoreline in the early $20^{\text {th }}$ century were not farmers, but employed, thus the agricultural land use was minimal. This is also supported by the diatom data (not shown here), which did not show any indication of eutrophication as no taxa preferring elevated nutrient concentrations occurred during the last centuries.

The sole known potentially relevant event that occurred in Lake Kivijärvi during the 1920s was the beginning of intense fishing activity, which resulted in large vendace (Coregonus albula Linneaus) catches since the 1920s (S. Peronius, personal communication). Planktivorus fish are known to target large-size zooplankton Zaret, 1980), and vendace has been noted to prefer large cladocerans, such as Eubosmina and Daphnia, in Swedish (Hamrin, 1983) and Finnish (Viljanen, 1983) forest lakes. Cladoceran remains are poorly digested during their passage through fish guts (Sutela and Huusko, 1993; Riccardi, 2000) and Daphnia remains have been proved to survive the passage through vendace and whitefish digestive apparatus (Sutela and Huusko, 2000). The poor preservation level of Daphnia spines before the 1920s may therefore reflect a higher proportion of partly digested Daphnia in the correspondent sediment samples. The intensive removal of fish may have also increased the abundance of invertebrate predators (Milardi et al., 2016). Elevated invertebrate predation has been noted to induce thickening and hardening of Daphnia carapaces (Rabus et al., 2013). This might be the reason for the appearance of hard and thick remains, which are more resistant to post-mortem degradation. However, the lack of variations of Eubosmina size suggests that no high magnitude changes in invertebrate predation have occurred during the shift in Daphnia preservation. Moreover, the very low number of Chaoborus mandibles in our samples $(<2$ per sample) allow no assumptions regarding changes of predation regime in Lake Kivijärvi, because according to Quinlan and Smol (2010) a minimum of 5 to 10 mandibles is needed to reliably assess Chaoborus assemblages. High head helmet and a long spine are also considered as general defensive structures, which are grown by Daphnia when they are subjected to invertebrate predation (Laforsch and Tollrian, 2004). The fact that only Daphnia remains with long spine and high helmet were identified throughout the core studied, further supports the hypothesis that only little change in the intensity of invertebrate predation occurred at Lake Kivijärvi during the last $\sim 250$ years.

The results presented here suggest the potential of Daphnia caudal spine to be used as indicator of cladoceran degradation in sediments. However, more work is still necessary to further evaluate this potential. For ex- ample, type and degree of degradation of caudal spines caused by fish ingestion, should be experimentally assessed. Similarly, the microbial degradation of Daphnia remains should be tested in a controlled environment, in order to clarify the degradation process and the actual microbial community involved in Daphnia degradation.

\section{CONCLUSIONS}

This work provides first evidence for the potential use of caudal spine as indicator of Daphnia degradation in sediments. Historical information and sediment geochemistry suggest that no large-scale environmental or hydrological changes have affected the remote Lake Kivijärvi during the early decades of the $20^{\text {th }}$ century, when major changes in Daphnia preservation occurred. On the other hand, the historical data and the diatom-inferred $\mathrm{pH}$ profile indicate the increase in fishing activity after 1920 and the steady decrease in water $\mathrm{pH}$ from the beginning of $20^{\text {th }}$ century till the 1960 s as possible drivers of spine preservation of Daphnia. Though more work is clearly needed to experimentally verify the role of these factors in affecting Daphnia preservation, these preliminary results shed new light on the issue of large cladoceran preservation in lake sediments. This aspect is still poorly explored, but might have the potential to improve the reliability of palaeolimnological reconstructions.

\section{ACKNOWLEDGMENTS}

This work was funded by Tellervo and Jussi Walden foundation, Soil protection and environmental protection technology (MUTKU) society and Kainuu Centre for Economic Development, Transport and the Environment. We are grateful to Jussi Leppänen for assistance in the field and to two anonymous reviewers for their valuable comments and constructive suggestions which greatly improved this manuscript.

\section{REFERENCES}

Ahtiainen M, 1992. The effects of forest clear-cutting and scarification on the water quality of small brooks. Hydrobiologia 243/244:465-473.

Appleby PG, Nolan PJ, Gifford DW, Godfrey MJ, Oldfield F, Anderson NJ, Battarbee RW, 1986. ${ }^{210} \mathrm{~Pb}$ dating by low background gamma counting. Hydrobiologia 141:21-27.

Appleby PG, Richardson N, Nolan PJ, 1991. ${ }^{241}$ Am dating of lake sediments. Hydrobiologia 214:35-42.

Arvola L, George G, Livingstone DM, Järvinen M, Blenckner T, Dokulil MT, Jennings E, Aonghusa CN, Noges P, Noges T, Weyhenmeyer GA, 2010. The impact of the changing climate on the thermal characteristics of lakes, p. 85-101. In: G. George (ed.), The impact of climate change on European 
lakes, Aquatic Ecology Series 4. Springer Science+Business Media B.V.

Aumen NG, 1980. Microbial succession on a chitinous substrate in a woodland stream. Microbial Ecol. 6:317-327.

Bennett K, 1996. Determination of the number of zones in a biostratigraphical sequence. New Phytol. 132:155-170.

Birks HJB, Gordon AD, 1985. Numerical methods in Quaternary pollen analysis. Academic Press, London: $317 \mathrm{pp}$.

Brandt DS, 1989. Taphonomic grades as a classification for fossiliferous assemblages and implications for paleoecology. Palaios 4:303-309.

Czeczuga B, Kozłowska M, Godlewska A, 2002. Zoosporic aquatic fungi growing on dead specimens of 29 freshwater crustacean species. Limnologica 32:180-193.

Deevey ES, 1964. Preliminary account of fossilization of zooplankton in Rogers Lake. Int. Ver. Theor. Angew. Limnol. Verh. 15:981-992.

Ebert D, 2005. Ecology, and evolution of parasitism in Daphnia. National Library of Medicine (US), National Center for Biotechnology Information, Bethesda: $110 \mathrm{pp}$.

Eggermont H, Martens K, 2011. Preface: Cladocera crustaceans: sentinels of environmental change. Hydrobiologia 676: 1-7.

European Union, 2000. Directive 2000/60/EC of the European Parliament and the council of 23 October 2000 on establishing a framework for community action in the field of water policy. Eur. J. Commun. L327:1-72.

Frey DG, 1986. Cladocera analysis, p. 667-692. In: B.E. Berglund (ed.), Handbook of palaeoecology and palaeohydrology. J. Wiley \& Sons Ltd.

Frey DG, 1991. First subfossil records of Daphnia headshields and shells (Anomopoda, Daphniidae) about 10000 years old from northernmost Greenland, plus Alona guttata (Chydoridae). J. Paleolimnol. 6:193-197.

Gilbert RO, 1987. Statistical methods for environmental pollution monitoring. Van Nostrand Reinhold, New York: 336 pp.

Gooday GW, 1990. The ecology of chitin degradation. Adv. Microb. Ecol. 11:387-430.

Gylden CW, 1863. [Sydöstra delen af Uleåborgs län med norra delen af Kuopio län].[Map in Finnish]. Sektionen D4. Karta öfver Finland.

Hammer Ø, Harper DAT, Ryan PD, 2001. PAST: Paleontological statistics software package for education and data analysis. Palaeontol. Electron. 4:1-9.

Hamrin SF, 1983. The food preference of vendace (Coregonus albula) in South Swedish forest lakes including the predation effect on zooplankton populations. Hydrobiologia 101:121-128.

Irannezhad M, Marttila H, Kløve B, 2014. Long-term variations and trends in precipitation in Finland. Int. J. Climatol. 34:3139-3153.

Johnsen GH, Raddum GG, 1987. A morphological study of two populations of Bosmina longispina exposed to different predation. J. Plankton Res. 9:297-304.

Kauppi S, Mannio J, Hellsten S, Nysten T, Jouttijärvi T, Huttunen M, Ekholm P, Tuominen S, Porvari P, Karjalainen A, SaraAho T, Saukkoriipi J, Maunula M, 2013. [Arvio Talvivaaran kaivoksen kipsisakka-altaan vuodon haitoista ja riskeistä vesiympäristölle. Suomen ympäristökeskuksen raportteja 11/2013].[Book in Finnish]. Suomen Ympäristökeskus, Helsinki: 90 pp.
Kerfoot WC, 1981. Long-term replacement cycles in cladoceran communities: A history of predation. Ecology 62:216-233.

Kersalo J, Pirinen P, 2009. [The climate of Finnish regions].[Book in Finnish]. Finnish Meteorological Institute. Yliopistopaino, Helsinki: 185 pp.

Kidwell SM, Flessa KW, 1995. The quality of fossil record: populations, species and communities. Annu. Rev. Ecol. Syst. 26:269-299.

Korhola A, 1999. Distribution patterns of Cladocera in subarctic Fennoscandian lakes and their potential in environmental reconstruction. Ecography 22:357-373.

Korosi JB, Jeziorski A, Smol JP, 2011. Using morphological characters of subfossil daphniid postabdominal claws to improve taxonomic resolution within species complex. Hydrobiologia 676:117-128.

Korosi JB, Kurek J, Smol JP, 2013. A Review on utilizing Bosmina size structure archieved in lake sediments to infer historic shifts in predation regimes. J. Plankton. Res. 35:444-460.

Köllner KE, Carstens D, Keller E, Vazquez F, Schubert CJ, Zeyer J, Bürgmann H, 2012. Bacterial chitin hydrolysis in two lakes with contrasting trophic statuses. Appl. Environ. Microbiol. 78:695-704.

Laforsch C, Tollrian R, 2004. Inducible defenses in multipredator environments: cyclomorphosis in Daphnia cucullata. Ecology 85:2302-2311.

Lampert W, 2011. Daphnia: Development of a model organism in ecology and evolution. In: O. Kinne (ed.), Excellence in Ecology, Book 21. International Ecology Institute.

Kauppi P, Anttila P, Kenttämies K, 1990. Introduction to this book, p. XIII-XVIII. In: P. Kauppi, P. Anttila, K. Kenttämies (eds.), Acidification in Finland. Springer-Verlag.

Lotter, AF, Juggins S, 1991. PLOPROF, TRAN and ZONE. Programs for plotting, editing and zoning of pollen and diatom data. INQUA Commmission for the study of the Holocene, Working Group on Data Handling Methods, Newsletter 6.

Mancini M, Comoli P, Margaritora FG, 1999. An unusual type of Daphnia head shields from plankton and sediments of Himalayan lakes. J. Limnol. 58:29-32.

Meriläinen J, Huttunen P, 1990. Lake acidification in Finland. Phil. Trans. R. Soc. Lond. B 327:423-425.

Mikkonen S, Laine M, Mäkelä HM, Gregow H, Tuomenvirta H, Lahtinen M, Laaksonen A, 2014. Trends in the average temperature in Finland, 1847-2013. Stoch. Env. Res. Risk. A. 29:1521-1529.

Milardi M, Siitonen S, Lappalainen J, Liljendahl A, Weckström J, 2016. The impact of trout introductions on macro-and micro-invertebrate communities of fishless boreal lakes. J. Paleolimnol. 55:273-287.

Naeher S, Smittenberg RH, Gilli A, Kirilova EP, Lotter AF, Schubert CJ, 2012. Impact of recent lake eutrophication on microbial community changes as revealed by high resolution lipid biomarkers in Rotsee (Switzerland). Org. Geochem. 49:86-95.

Nykänen M, Vakkilainen K, Liukkonen M, Kairesalo T, 2009. Cladoceran remains in lake sediments: a comparison between plankton counts and sediment records. J. Paleolimnol. 42:551-570.

Pennington W, 1984. Long-term natural acidification of upland sites in Cumbria: Evidence from post-glacial lake sediments, p. 28-46. In: Freshwater Biological Association (eds.), Fifty- 
second annual report for the year ended 31st March 1984. Freshwater Biological Association, Ambleside.

Peters RH, de Bernardi R, 1987. Daphnia. Mem. Ist. Ital. Idrobiol. 45:1-502.

Quinlan R, Smol JP, 2010. The extant Chaoborus assemblage can be assessed using subfossil mandibles. Freshwater Biol. 55:2458-2467.

Rabus M, Söllardl T, Clausen-Schaumann H, Laforsch C, 2013. Uncovering ultrastructural defences in Daphnia magna - an interdisciplinary approach to assess the predator-induced fortification of the carapace. PLoS One 8:e67856.

Rask M, Nyberg K, Markkanen S-L, Ojala A, 1998. Forestry in catchments: effects on water quality, plankton, zoobenthos and fish in small lakes. Boreal Env. Res. 3:75-86.

Renberg I, Hansson H, 2008. The HTH sediment corer. J. Paleolimnol. 40:655-659.

Riccardi N, 2000. Comparison of different stoichiometric methods for the estimation of proximate biochemical composition of crustacean zooplankton and some considerations on energy transfer to planktophagous fish. J. Limnol. 59:179-185.

Sarmaja-Korjonen K, 2002. Multi-proxy data from Kaksoislammi Lake in Finland: dramatic changes in the late Holocene cladoceran assemblages. J. Paleolimnol. 28:287-296.

Sarmaja-Korjonen K, 2007. Subfossil shell margins and caudal spines of Daphnia in Finnish lake sediments - Is Daphnia underrepresented in cladoceran analysis? Studia Quaternaria 24:61-64.

Schmidt R, Wunsam S, Brosch U, Fott J, Lami A, Löffler H, Marchetto A, Müller MW, Pražáková M, Schwaighofer B, 1998. Late and post-glacial history of meromictic Längsee (Austria), in respect to climate change and anthropogenic impact. Aquat. Sci. 60:56-88.

Seda J, Petrusek A, 2011. Daphnia as a model organism in limnology and aquatic ecology: introductory remarks. J. Limnol. 70:337-344.

Seppä H, Weckström J, 1999. Holocene vegetational and limnological changes in the Fennoscandian tree-line area as documented by pollen and diatom records from Lake Tsuolbmajavri, Finland. Ecoscience 6:621-635.

Smol JP, 1992. Paleolimnology: an important tool for effective ecosystem management. J. Aquat. Ecosyst. Health 1:49-58.

Sprules WG, Carter JCH, Ramcharan CW, 1984. Phenotypic as- sociations in the Bosminidae (Cladocera): zoogeographic patterns. Limnol. Oceanogr. 29:161-169.

Sutela T, Huusko A, 1994. Digestion of zooplankton in the alimentary tract of vendace (Coregonus albula) larvae. J. Fish. Biol. 44:591-596.

Sutela, T, Huusko A, 2000. Varying resistance of zooplankton prey to digestion: Implications for quantifying larval fish diets. T. Am. Fish. Soc. 192:545-551.

Sweetman JN, Smol JP, 2006. Reconstructing fish populations using Chaoborus (Diptera:Chaoboridae) remains - a review. Quat. Sci. Rev. 25:2013-2023.

Swiontek Brzezinska M, Lalke-Porczyk E, Donderski W, 2008. Utilization of shrimp waste as a respiration substrate by planktonic and benthic microorganisms. Pol. J. Environ. Stud. 17:273-282.

Szeroczyñska K, Zawisza E, 2005. Daphnia remains from the sediment of lake Somaslampi (NW Finnish Lapland) and Lake Wigry (NE Poland). Studia quaternaria 22:55-57.

Szeroczyñska K, Sarmaja-Korjonen K, 2007. Atlas of subfossil Cladocera from Central and Northern Europe. Friends of the Lower Vistula Society: 84 pp.

Tang KW, Bickel SL, Dziallas C, Grossart H-P, 2009. Microbial activities accompanying decomposition of cladoceran and copepod carcasses under different environmental conditions. Aquat. Microb. Ecol. 57:89-100.

Viljanen M, 1983. Food and food selection of cisco (Coregonus albula L.) in a dysoligotrophic lake. Hydrobiologia. 101: 129-138.

Virkkanen J, Tikkanen M, 1998. The effects of forest ditching and water level changes on sediment quality in a small lake, Perhonlampi, Central Finland. Fennia 176:301-317.

Väliranta M, Weckström J, Siitonen S, Seppä H, Alkio J, Juutinen S, Tuittila E-S, 2011. Holocene aquatic ecosystem change in the boreal vegetation zone of northern Finland. J. Paleolimnol. 45:339-352.

Weckström J, Korhola A, Blom T, 1997. The relationship between diatoms and water temperature in thirty subarctic Fennoscandian lakes. Arctic Alpine Res. 29:75-92.

Wurzbacher CM, Barlocher F, Grossart HP, 2010. Fungi in lake ecosystems. Aquat. Microb. Ecol. 59:125-149.

Zaret TM, 1980. Predation and freshwater communities. Yale University Press, New Haven: 185 pp. 